\title{
EL CONVENTO DE CHARO Y SUS MURALES
}

\author{
$\mathbf{P} \mathbf{O}$
}

\section{RAUL FLORES GUERRERO}

$\mathrm{C}^{\mathrm{N}}$ el año de 1550 se fundaba la villa de San Miguel Charo MatlatE zinco de Michoacán, en territorios pertenecientes al vasto marquesado del Valle de Oaxaca, que se extendía desde la cumbre del Ajusco hasta los valles de la antigua Antequera.

Del pasado prehispánico de Charo dan razón dos versiones coloniales; una, la del cronista fray Alonso de Larrea; otra, la del fraile agustino Diego Basalenque, consignadas ambas por fray Matías de Escobar en su Americana Thebaida, escrita en el propio convento de Charo en 1729.

Refiere Larrea que, poco tiempo antes de la Conquista, el emperador de México, en un esfuerzo por someter a los rebeldes tarascos a su férula imperialista, le ofreció la libertad a un prisionero matlatzinca, Tlahuitzoli -quien habia sido el terror de las huestes mexicanas-, con la condición de que obtuviera una victoria definitiva sobre los irreductos súbditos del Caltzontzin. Con tai objeto puso bajo su mando "el mayor ejército que había juntado aquel imperio", sin embargo, la fuerza militar que había hecho inconquistables a los tarascos se impuso una vez más sobre las armas mexicanas, tecas y matlatzincas que constituían el ejército invasor, cayendo prisionero el valiente Tlahuitzoli y gran número de sus guerreros. Aquellos que se salvaron del sacrificio fueron distribuidos, para "asegurarlos", en diversas partes del territorio purépecha: los tecas mercenarios en Pátzcuaro, Jacona y Tángamandapeo, los me- 
xicanos en las provincias de Zacatula y los matlatzincas o "pirindas" - Los de enmedio- precisamente en medio del reino, entre Undaneo e Indaparapeo. Estos núcleos nahuas, aunque dominados, conservaron sus ancestrales costumbres y su lengua hasta la actualidad.

Basalenque, por su parte, refiere que en aquel tiempo gobernaba a los tarascos el Characu o "Rey niño", desde su capital en Tzintzuntzan. Aprovechando la ocasión y la corta edad del soberano tarasco los tecas trataron de invadir el señorio del Caltzontzin $y$ ante este peligro se decidió, en junta de guerra, solicitar ayuda al extranjero. Los matlatzincas del Valle de Toluca aceptaron prestar su auxilio a los tarascos, tanto por "lograr sus intereses, como por medir sus armas con los tecas y ver si eran tan valerosos como lo publicaba la fama". Matlatzincas y tarascos, bajo el mando del general de los primeros, vencieron rotundamente a sus enemigos; los pocos tecas que quedaron con vida fueron sacrificados en los sangrantes altares del dios Curicaberi en Zacapu. Llegado el momento de la paga los matlatzincas se ofrecieron a servir como aliados a los tarascos en todas sus batallas, siempre y cuando el rey les concediera tierras fértiles en donde establecerse. El Characu aceptó la oferta y les asignó el territorio comprendido entre Undaneo e Indaparapeo " $y$ como quedaron en este lugar - dice Basalenque - se empezaron a denominar Pirindas". Queriendo demostrar su agradecimiento dedicaron la nueva colonia al soberano tarasco, al Characu o Infante de los purépechas, llamándola Charo.

La segunda de estas crónicas es la más cercana a la posible realidad histórica, y ello se debe a que Basalenque escribió su relación precisamente en el propio convento de Charo en donde obtuvo toda clase de testimonios directos, entre éstos el de un libro escrito por un recién bautizado, lo que obliga a aceptar su versión sobre la de Larrea, quien redactó su historia "sin conocimiento de estos indios desde Querétaro" según asienta Escobar.

Una vez realizada la Conquista española el Caltzontzin y el jefe matlatzinca se trasladaron a México, para someterse voluntariamente a quienes los habían liberado de sus eternos enemigos los mexicanos. El primero regresó a sus dominios convertido en don Francisco I, rey de Tzintzuntzan y el segundo recibiría, más tarde, el nombre de Juan de San Miguel, bautizado por el primer evangelizador de los pirindas de Charo, el incansable franciscano fray Juan de San Miguel. 
I a advocación del pueblo de San Miguel, se debe al hecho de haber sido el seráfico fray Juan el primer religioso que predicó el cristianismo a los indios del lugar. El cronista Escobar, no sin cierto celo agustiniano, refiere que "por estos montes entró predicando fray Juan de San Miguel más poco tiempo duró, pues contento con bautizar al principal y a otros pocos, se pasó adelante, quedando los indios tan gentiles como antes". 1

En una de sus visitas, el obispo don Vasco de Quiroga reconoció el abandono espiritual en que se hallaban los matlatzincas de Michoacán y cedió para su cristianización todos estos núcleos indigenas a los agustinos, de tal modo que, en el siglo xvir pudo ufanarse Escobar de que "todos los de esta lengua nos pertenecen en Mechoacán y entre ellos los de Charo, cabecera de los pirindas..."

El provincial de los agustinos en México, en ese tiempo el insigne filósofo fray Alonso de la Veracruz, designó a fray Pedro de San Jerónimo para fundar convento en la villa de San Miguel Charo, séptimo de la orden en Michoacán, lo que daria lugar al mismo Escobar para titular su crónica la agustiniana Thebaida con la barroca razón de que "si las siete pirámides y la Thebaida hacían plausible en el Mundo Viejo a Egipto, en este Nuevo Mundo puede hacer célebre al reino de Mechoacán la agustiniana Thebaida y los siete conventos... que, como pirámides, elevaron en esta provincia nuestros primitivos padres". Se refiere, concretamente, a los de Tiripitío, Tacámbaro, Valladolid, Yuririapúndaro, Cuitzeo, Guango y Charo, convento, éste último, "nada inferior en grandeza a los otros seis". Llegado fray Pedro de San Jerónimo al pueblo que se le había designado dedicó los tres montes circundantes a San Miguel, a San Juan Evangelista y a San Bartolomé, erigiendo en el primero la iglesia que más tarde se transformó en el convento definitivo y levantando en los otros dos pequeñas capillas que, descuidadas por la preponderancia del templo principal, han desaparecido. "Y así quedó fundada la villa de Charo sobre montes."

El paisaje de Charo, como el de tantas otras regiones de México, se ha transformado, por la erosión y desforestación secular, de un auténtico paraiso en un desierto. Todavia a principios del siglo xvirI "era de gran alegría ver la mucha arboleda que tiene, entre la que se preciben las casas..., mirándose el campo frondoso y verde..., enmarcado por

1 Fray Matías de Escobar. Americara Thebaida México, 1924. 
dos ríos que lo amurallan con paredes de cristal". " Se ha realizado alli el mismo proceso de destrucción regional que en la Mixteca, en el Valle de Puebla y en el de México hace inexplicable la existencia de enormes fundaciones religiosas en lugares hoy pobres y polvorientos, pero ricos y verdeantes en su tiempo. La fertilidad de la tierra en Charo entusiasmó por igual a los antiguos pirindas, a los apostólicos agustinos y a los terratenientes coloniales, uno de los cuales, amparándose de su carácter de heredero del Caltzontzin, trató de posesionarse de aquellas tierras a mediados del siglo xvir, fracasando ante los agustinos que supieron mantener su feudo con toda energía.

$\mathrm{Ni}$ el mismo Basalenque puede superar al cronista Escobar en la narración de la fundación y las características del convento de Charo en sus primeros años. Su entusiasmo criollo, su barroquismo literario, su ágil expresión, hacen de su Americana Thebaida un documento lleno de vitalidad, rico en anécdotas y poéticas descripciones.

Para Escobar, el convento de Charo, desde su fundación, es un verdadero monumento sinfónico. Dulces armonias celestiales orientan al fraile San Jerónimo $y$ a sus indios en la localización del terreno para la fundación, "moviendo las voluntades a que dejando un lugar pasasen al sitio de las voces con la nueva fábrica", hasta que al fin, después de tres intentos, las roces guiadoras cesaron, indicando asi el lugar apropiado para la construcción. Esta musicalidad de Charo cundió, según las lucubraciones dieciochescas de Escobar, a todas las imágenes que ocuparon los altares de la iglesia o los nichos de la sacristia a través de la vida secular del convento. Un Cristo de pasta de caña, conocido como El Señor de la Lámpara, salido indudablemente de la escuela artística que Don Vasco de Quiroga tenía en Pátzcuaro, será para el extraordinario cronista barroco de los agustinos no sólo "una obra maravillosa a donde no llegaron los buriles de los Fidias ni Licipos", sino además un auténtico "crucifijo instrumento músico". $Y$ añade: "¿Qué más sonoro instrumento, qué cítara más suave que ese divino crucifijo suspenso, como órgano, en el sauce de la cruz y que tirante de tres clavos de hierro está constantemente sonando?" A las armonias de este "sagrado iris que lleva el instrumento de la cruz al hombro", al sonido en las calles de "esta sagrada citara" se debieron la precipitación y la contención de las lluvias, las crecidas $y^{+}$menguas de los rios, el alivio de las enfermedades

2 Escobar, p. 774. 
y la benignidad de las epidemias durante mucho tiempo en Charo. La efigie de San Juan de Sahagún, el agustiniano salmantino, tenia en el pecho "en lugar del racional un hueso, reliquia del propio santo". "Tibia (hueso) es lo mismo que flauta -explica Escobar en su afán por relacionar a todo con la musicalidad de su convento- y sólo con echarlo al agua y darla ésta a beber a los enfermos se ven maravillas." También una escultura de la Concepción, despucis del derrumbe de la torre en 1661, "quedó en pié como cítara y sin recibir lesiones". Claro está que los religiosos que vivieron en Charo $\mathbf{y}$, después de muertos, fueron enterrados en la sacristia, fueron los "venerables citaristas..., inúsicos sepultados Davides", siendo el principal el fundador, fray Pedro de San Jerónimo. ${ }^{3}$

Este no se concretó a dirigir la obra arquitectónica y ornamental del convento, sino que, inprovisándose como planificador y temporal encomendero, dividió en cuatro barrios la villa, cada uno con su correspondiente iglesia, y repartió las tierras y ejidos entre los naturales.

En la fábrica conventual comenzó a levantar los muros de la iglesia c hizo el claustro en donde mandó pintar los estupendos frescos que nos ocuparán lineas adelante; construyó además la sacristía, a la que añadió el refectorio, la porteria, el antecoro "con más de seis celdas y un dormitorio bajo, estrecho y humilde, a la moda del antiguo convento de Tiripitio, todo lo cual aún persevera como si lo acabaran de hacer". Fuć precisamente al llegar, en la elevación del templo, a la construcción de las ventanas, cuando le asaltó la muerte en 1578 .

Los frailes que le sucedieron en el priorato de Charo continuaron tenazmente con la obra iniciada por fray Pedro de San Jerónimo. Fray Francisco de Acosta casi dió fin a "la iglesia y otras oficinas del convento..., y echó en la sacristia el ornamento más rico que por aquellos tiempos y aún por éstos ha visto este nuevo mundo" ... "Hizo el cañón de la iglesia y su portada que, en cuanto a fachada, es la mejor de todas las iglesias de la provincia." A su muerte, acaecida en 1606, fray Juan de Baena "dió fin al hermoso cañón de la iglesia y llenó de plata y ornamentos la sacristía". Refiere Escobar que en tiempos del propio Baena "se terminó el convento alto, por las manos de fray Diego de Soto", 5 lo cual no deja de extrañar después que él mismo afirma que

3 Escobar, pp. 780 y ss.

4 Idem., p. 794.

5 Idern., p. 795. 
fray Pedro de San Jerónimo “dejó hechos unos claustros bajos, sin fundamentos para recibir altos"." Si es que alguna vez existió este claustro alto, en la actualidad no queda ninguna huella.

Después de Baena llegó como prior de Charo el venerable fray Diego Basalenque, más conocido por sus escritos y su labor como evangelizador que por sus obras materiales. No obstante que su paso no dejó su impronta en las piedras de los muros, su recuerdo está ligado intimamente con el convento de Charo, en donde murió $y$ vive aún entre las gentes del pueblo que veneran su sillón de piedra, colocado en la porteria, a manera de reliquia.

Fray Simón Salguero, pintor a quien se debe el retrato más fiel de Basalenque y hermano de fray Pedro Salguero, biógrafo del mismo, dió los últimos toques importantes al convento y a la iglesia. "Hizo el retablo mayor, doró la iglesia, fabricó otro retablo y en el convento puso muchos y devotos lienzos." Indudablemente todo esto matizado ya por el espiritu barroco de la época. Durante su priorato, un terremoto derribó las bóvedas del coro y la torre, afectando, además, los muros de la iglesia, empero, el padre Salguero "en breves días reedificó con más primor lo que había destruido el terremoto". 7

El establecimiento agustiniano de Charo se asienta en un amplio terraplén elevado sobre el nivel del gran atrio arbolado, al que se asciende por una breve escalinata culminada por una doble cruz de Caravaca.

La fachada de la iglesia, de un sobrio barroquismo del siglo xvIr, está constituída por dos cuerpos y un remate. En el primero se abre la puerta, en un arco de medio punto sencillamente moldurado que descansa sus esfuerzos en sólidas jambas, apenas alteradas en su paño exterior por el claroscuro de un ligero rehundimiento y en cuya parte superior, insólitamente, penden dos rarísimas peras de piedra que quizás pretendieron ser borlas doctorales. A un lado y a otro, dos columnas de fuertes resonancias renancentistas escoltan a las estatuas de dos santos agustinos, amparados bajo las conchas de sus nichos respectivos.

El segundo cuerpo se asienta en un ancho basamento, ornamentado por la ritmica repetición de amplias molduras circulares en cuyo centro estalla una flor. La ventana, dividida por el clásico parteluz mi-

6 Escobar, p. 820.

7 Idem., p. 797. 
choacano ocupa, naturalemnte, la parte central y en los nichos de los intercolumnios laterales aparecen dos santas de la orden.

En el elevado remate triangular de la fachada las entrecalles de los dos primeros cuerpos culminan en pequeños frontones, asentados en basas geométricamente ornamentadas, $y$ en el nicho central, el más importante de la fachada, San Agustín cubre con su amplia capa pluvial a sus monjes, conformando la misma alegórica escena que aparece esculpida, con mayor detalle y perfección, en los templos de San Augustín de México y Oaxaca. Más arriba aún, como última posibilidad decorativa en el proceso ascencional de la fachada, el escudo de la orden agustina resalta sobre el aparejo visible de las piedras.

Al lado derecho del templo se irgue la torre que, para ser neoclásica y estar en un pueblo como Charo, es excelente. Su relativa pesadez se debe a la existencia de sólo dos cuerpos, precaución arquitectónica producto de la experiencia, que a través del tiempo, adquirieron los constructores del convento en temblores y derrumbes.

Los tres arcos de la portería están soportados por ágiles y esbeltas columnas, suavemente galibadas, y por encima de ellos se extiende un renacentista entablamento en el que los clásicos triglifos alternan con las metopas octupadas por el corazón de San Agustín. En la penumbra interior se descubre un confesonario, con su concha michoacana irradiando sus estrías en la cabecera, al que la tradición ha relacionado tan intimamente con el recuerdo del padre Basalenque que aún hoy en día es objeto de gran veneración entre los fieles del lugar; en este sillón indudablemente el anciano religioso se sentaba para confesar a los numerosos conversos de Charo. Hay que recordar aqui al cronista Grijalva que refiere que: "como eran los fieles tantos y tan bien enseñados en el fé, no se vaciaban las porterías en todo el dia de gente que se confesaba". ${ }^{8}$ Con todo, es éste el único caso de un confesonario situado directamente hacia el atrio. A partir de él se adosan al muro las bancas de piedra infalibles en toda portería conventural.

Un pasillo comunica el exterior con el claustro, iniciándose allí la decoración mural que el prior Pedro de San Jerónimo mandara pintar en el siglo xvi. De un lado, en escenas de franca filiación con grabados europeos de la época, aparece Cristo Rey de Burlas y Cristo en la Columna. En el otro, apenas visible por su deterioro, los pasajes evangélicos

8 Fr. Juan de Grijalva. Crónica de la orden de San Agustin, p. 147. 
de La Oración del Huerto y El Prendimiento del Nazareno, con los principales personajes que intervinieron en el acto: el traidor Judas Iscariote, San Pedro y el desorejado Maico.

El claustro, fresco y luminoso, es de un solo piso e indudablemente siempre ha sido así pues, no obstante la referencia de Escobar a un "convento alto", de él no hay ningún vestigio. Quizás el cronista agustino consideró como tal el antecoro, construido sobre el macizo arquitectónico que, tras la portería, limita por un lado al pasillo que sirve de acceso al claustro, única construcción en segundo piso.

Los frescos del claustro son, sin duda, el aspecto más interesante del convento, y tanto por su temática como por su calidad estética son dignos de ocupar un lugar especial en el panorama artístico de la pintura colonial. ${ }^{\circ}$ Están pintados a base de tres colores: el negro, utilizado en el dibujo de las figuras y en los oscuros hábitos de los frailes; el rosa, en el encarnado de las manos y de los rostros y el azul que, en ocasiones, da un toque de alegría a las pinturas al combinarse con el color rosado de los cuerpos. Predominan alli las escenas de martirios en las que, a decir de Escobar, fray Pedro de San Jerónimo "manifestó su ánimo en lo que mandó pintar pues puso los mayores martirios con que los tiranos mortificaron a los varones de nuestra religión". ${ }^{10}$

La primera escena, a la derecha, representa el martirio de un obispo. El agustino, con una absoluta indiferencia marcada en el rostro, un libro en la mano y la mitra depositada en el suelo, recibe una andanada de piedras que le arrojan cuatro fornidos jóvenes vestidos con calzas y calzón corto; uno de éstos lleva los proyectiles en una canasta, como si fueran flores escogidas previa y cuidadosamente. En la composición de este mural existe una armoniosa simetría, enfatizada por la posición de los brazos de los cuatro lapidadores.

El segundo martirio es el de un predicador que, asomando sobre la borda de un diminuto barco, muere flechado por dos arqueros vestidos a la manera medieval, ante la presencia angustiada de un grupo de mujeres que, arrodilladas, lucen la preciosa complicación de los pliegues de sus vestidos.

9 Hasta hace pocos años habían permanecido ocultos $y$ olvidados bajo una protectora capa de cal. Fueron dados a conocer por primera vez en unas notas escritas por el autor de este artículo para el Itinerario de los FF. CC. Nacionales de México.

10 Escobar, p. 794. 
Más adelante, junto a la puerta que comunica la clausura con Ja iglesia, un Ecce homo, triste y pensativo, cubierto con una capa pluvial, languidece bajo la presencia de dos personajes que salen de las nubes: un profeta hebreo, aquél que anunció la Pasión de Cristo en el Antiguo Testamento y San Juan Evangelista, relator de la vida y muerte de Jesús en los Evangelios.

En el muro siguiente, demasiada afectada por el transcurso del tiempo o la iconoclastia de algunos ocupantes del convento, se desarrolla una escena muy del gusto de los agustinos, la Tebaida, o sea el lugar de retiro y penitencia escogido por San Antonio en Fgipto, para ascética delicia de los más cristianos eremitas medievales. "Una montaña -escribe Escobar refiriéndose al mural mandado pintar por el prior de Charo- a la moda de las sierras de Tagaste y con gran semejanza a las de Egipto en la Tebaida, como diciendo lo que pensaba y guardaba (el prior) en su corazón: martirios y soledades." 11

La parte izquierda del claustro está dividida en dos grandes lienzos por una preciosa puerta central, abierta en arco de medio punto. Las dovelas, marcadas cada una por molduras rehundidas, ostentan en su centro la peculiar concha michoacana; por otra parte, en los espacios triangulares de las enjutas, aparece el corazón agustino encerrado en discos en relieve. A uno y otro lado se extienden dos frescos en manifiesta glorificación de la Orden. En uno de ellos un árbol surge del pecho de San Agustín, quien yace tendido en la parte inferior. De las prolongadas ramas del árbol agustiniano brota una gran cantidad de flores blancas, simétricamente dispuestas, que abriendo sus pétalos dejan salir los cuerpos de los principales santos, obispos y escritores agustinos en actitud de oración. Tal parece que Escobar tomó de aqui la idea para escribir, en la dedicatoria de su libro a sus superiores: "... todos se me representan pimpollos de la oliva Sapientísima Augustina... Arbol de Sabiduría." 12

El otro mural corresponde a las monjas. E1 árbol parte allí del pecho de Santa Mónica, madre del santo fundador que, acostada en displicente actitud, sostiene su cabeza con una mano y hojea un libro con la otra. Las ramas del árbol forman un armonioso entretejido central del que salen tres brazos vegetales hacia la derecha y tres hacia la izquierda. En la

11 Escobar, p. 794.

12 Item., p. XxIX. 
factura de este mural el pintor manejó el pincel con mayor libertad y buen gusto. Las monjas agustinas no salen, en general, de las flores, sino que se arrodillan en ellas además de que en sus manos y en sus rostros -alegres toques de color sobre la oscuridad del hábito- está implícita cierta feminidad que no deja de tener algo de fina coquetería. Si en el árbol genealógico de varones hay un ambiente de seriedad y rigidez, propias de una estricta regla, en el árbol genealógico femenino existe mayor humanidad y un magistral naturalismo; las ramas se ondulan y alguna hasta se doblega para no interrumpir la línea circular de la aureola de Santa Mónica; alternando con la floración monjil, crecen maduras granadas y grandes hojas. El águila de Hipona, a un lado, extiende sus alas negras, rompiendo con su presencia la posible monotonía de la composición. Este fresco es, sin lugar a duda, la obra maestra del pintor de Charo.

Los dos últimos murales del claustro, como los primeros, se refieren a dos martirios de frailes agustinos. En uno se representa una degollina: un soldado de armadura indefinida toma por el hábito, bruscamente, a los religiosos prisioneros para pasarlos a las manos de los verdugos que, armados de temibles espadas, les cortan la cabeza. El cuerpo de un fraile yace por tierra, su cabeza separada del cuello y, al fondo, a través de una puerta de profundo sabor renancentista, aparece el cuerpo de Cristo crucificado, destacando sobre una extraña montaña. Por desgracia, las letras que llenaban una elegante filacteria, pintada en uno de los ángulos, han desaparecido haciendo así inidentificable la escena.

En la pintura restante los agustinos, arrodillados y con las manos juntas, esperan el momento en que los crueles sayones los introduzcan en un gran perol en donde algunos de sus compañeros de religión se cuecen beatificamente. Ante la vista de los herejes atizando el fuego, uno de los frailes se ha desmayado y su cuerpo rigido ha quedado tendido sobre el suelo; es tal su rigidez que sus ropas conservan el aplomo de la verticalidad, dejando asomar apenas la punta de sus pies y su pálido rostro de mártir.

Cada escena está enmarcada, de manera estupenda, por dos columnas platerescas laterales y dos frisos, uno superior $y$ otro inferior, en los que, entre floridos roleos y cornucopias, aparecen escudos pasionarios, delicadas y juveniles monjas o desnudos angelillos danzantes. 


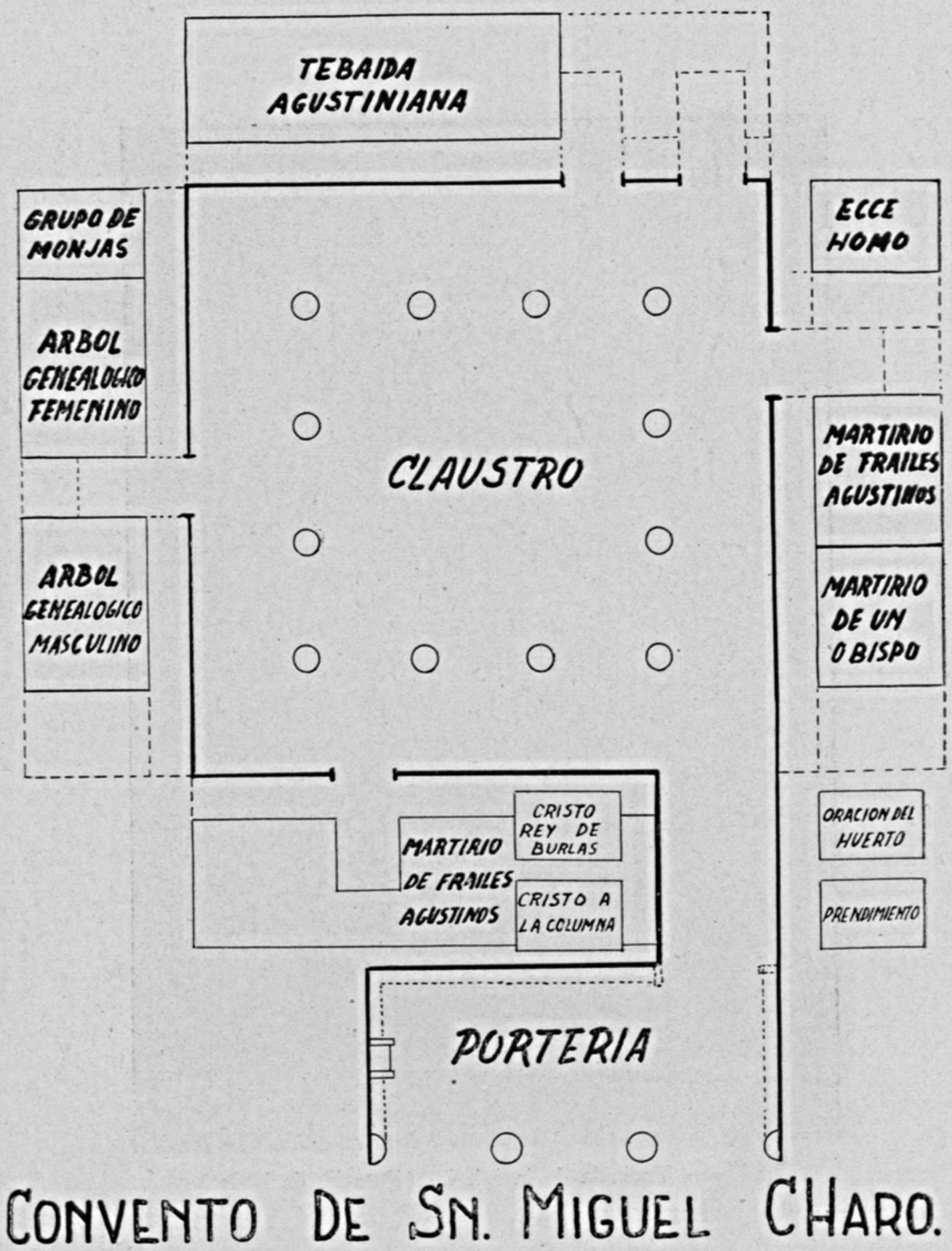

1. Planta de distribución de los murales. 


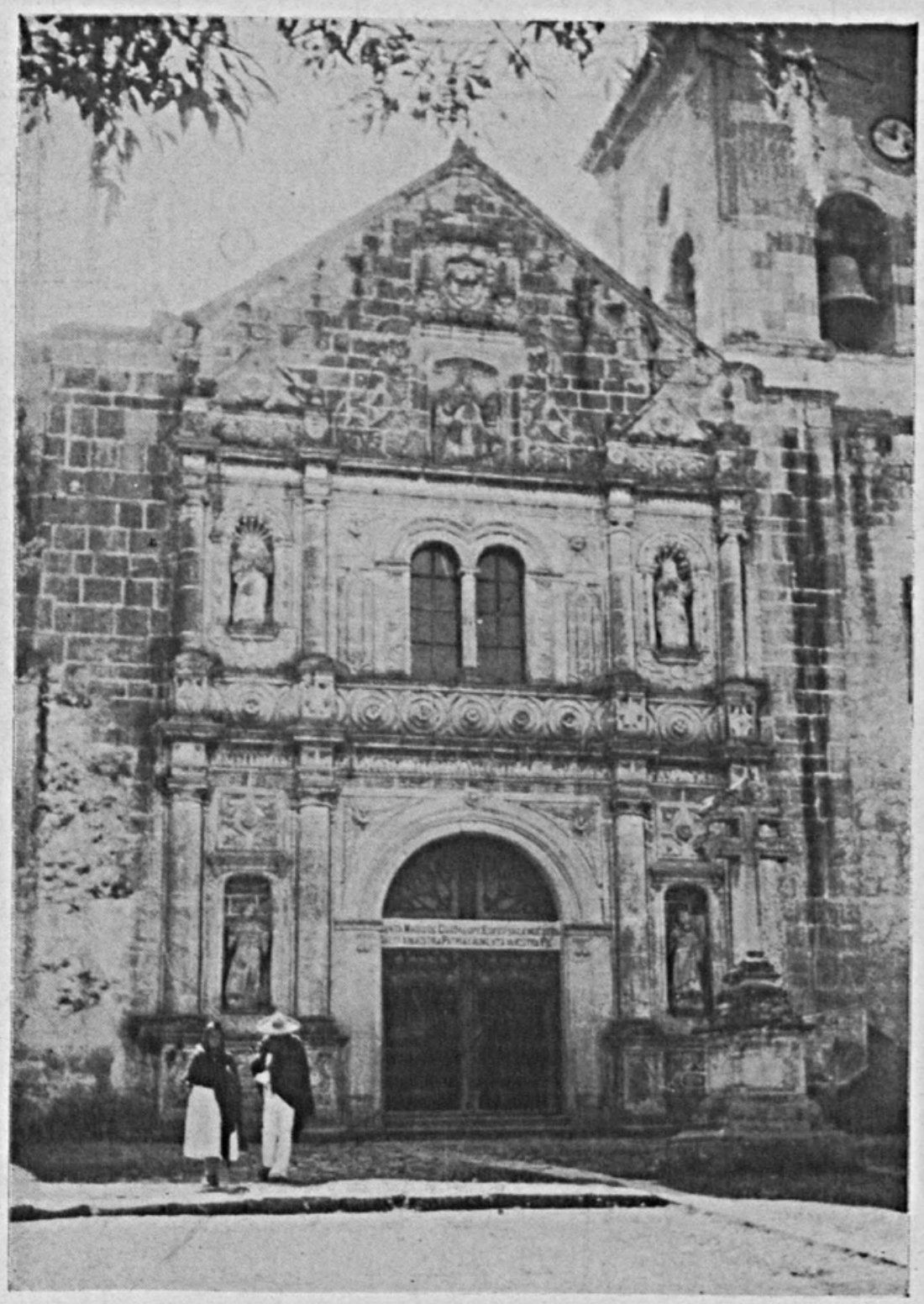

2. Charo. Fachada de la iglesia. (Foto F. de la M.) 


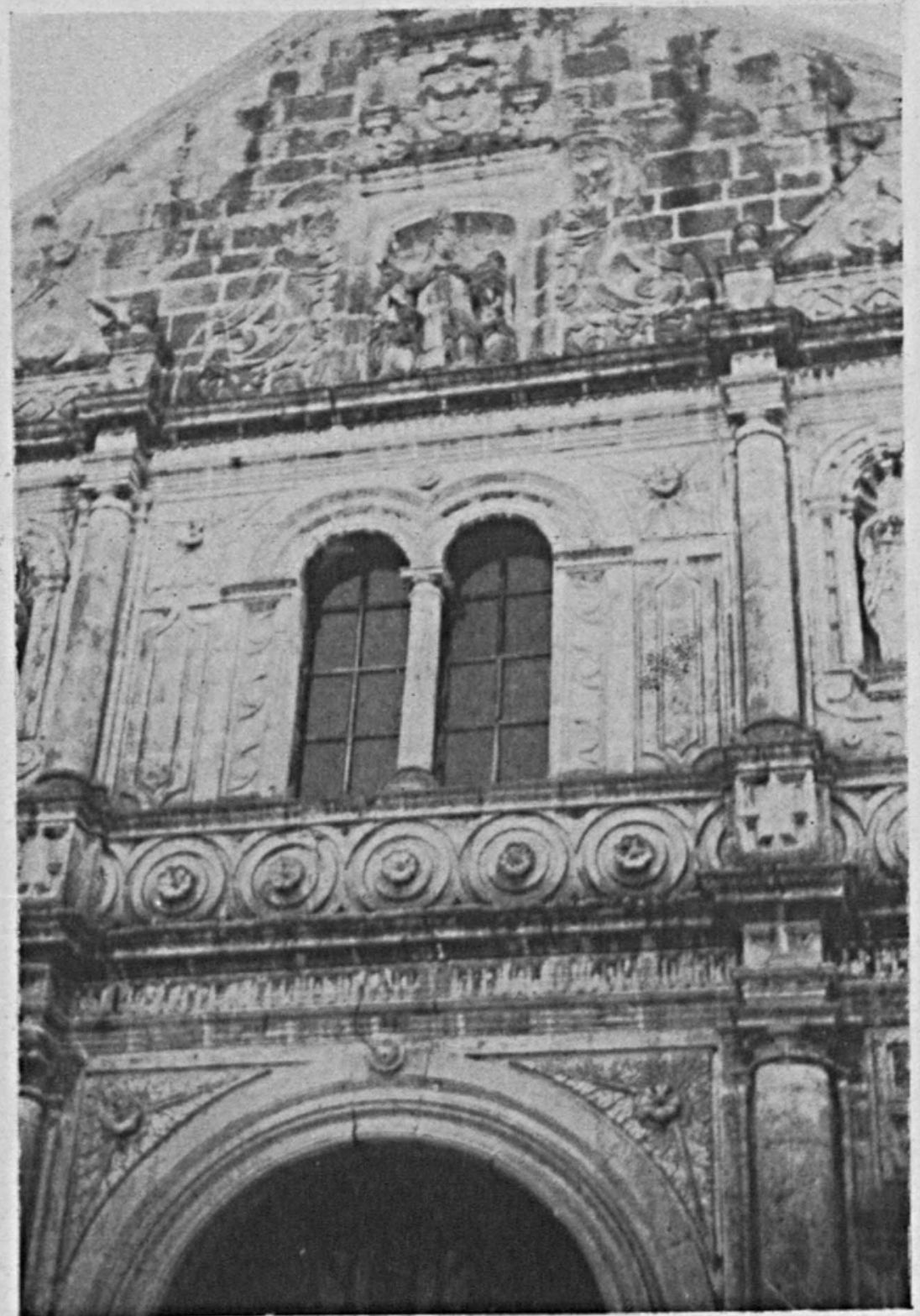

3. Charo. Fachada de la iglesia. Detalle. (Foto F. de la M.) 


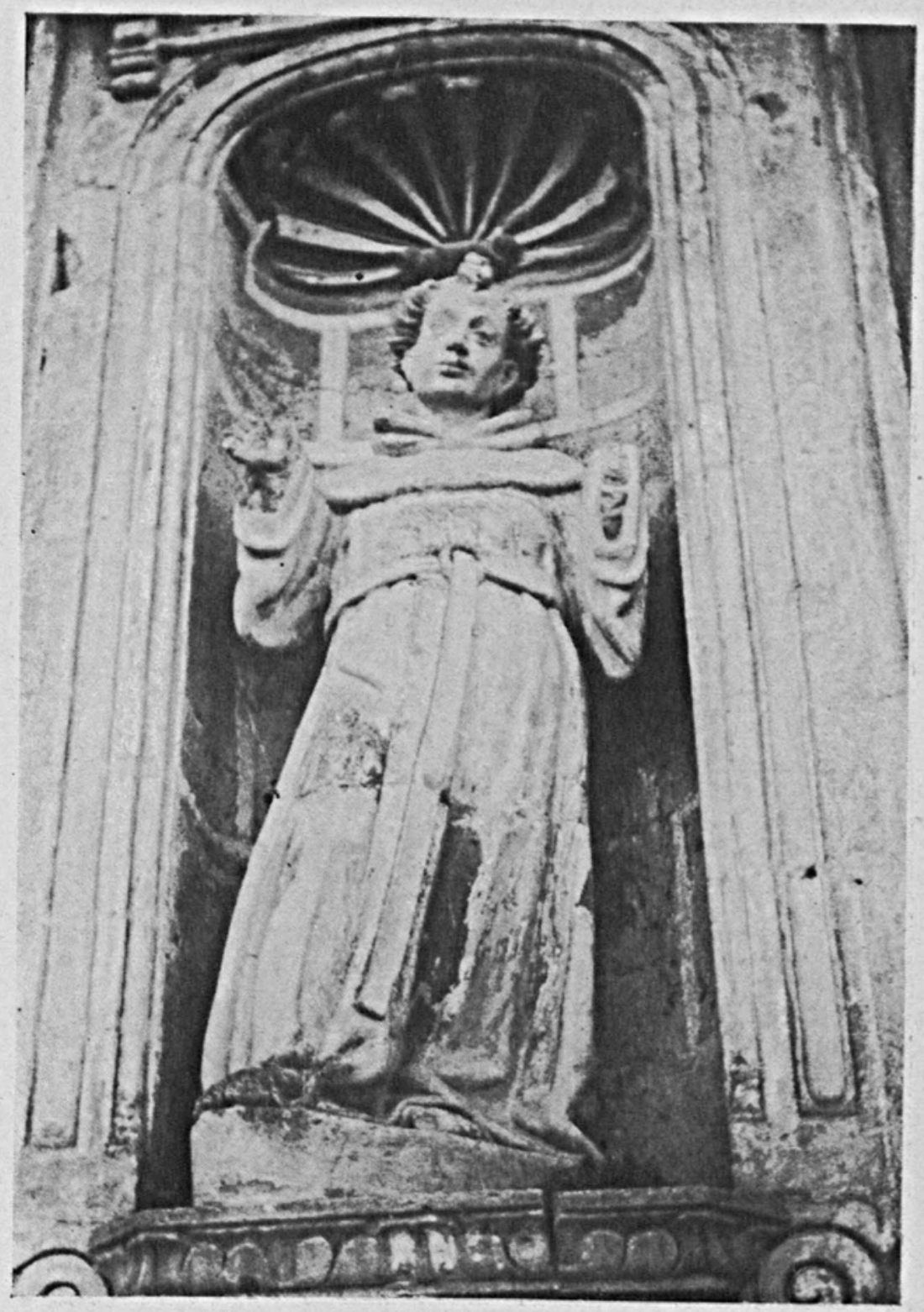

4. Charo. Escultura de San Nicolás Tolentino. (Foto F. de la M.) 
DOI: http://dx.doi.org/10.22201/iie.18703062e.1954.22.575

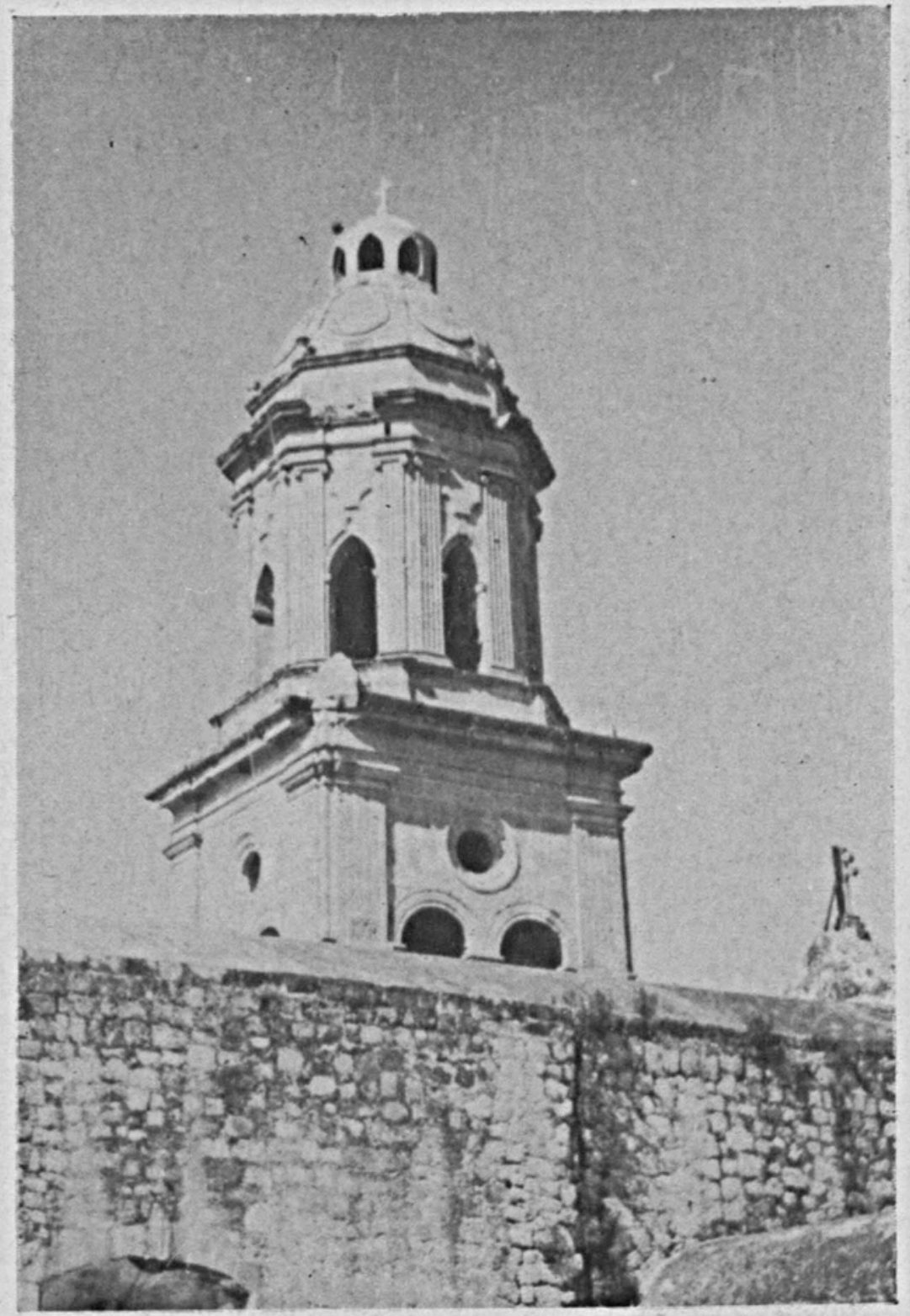

5. Charo. Torre. (Foto F. de la M.) 
DOI: http://dx.doi.org/10.22201/iie.18703062e.1954.22.575

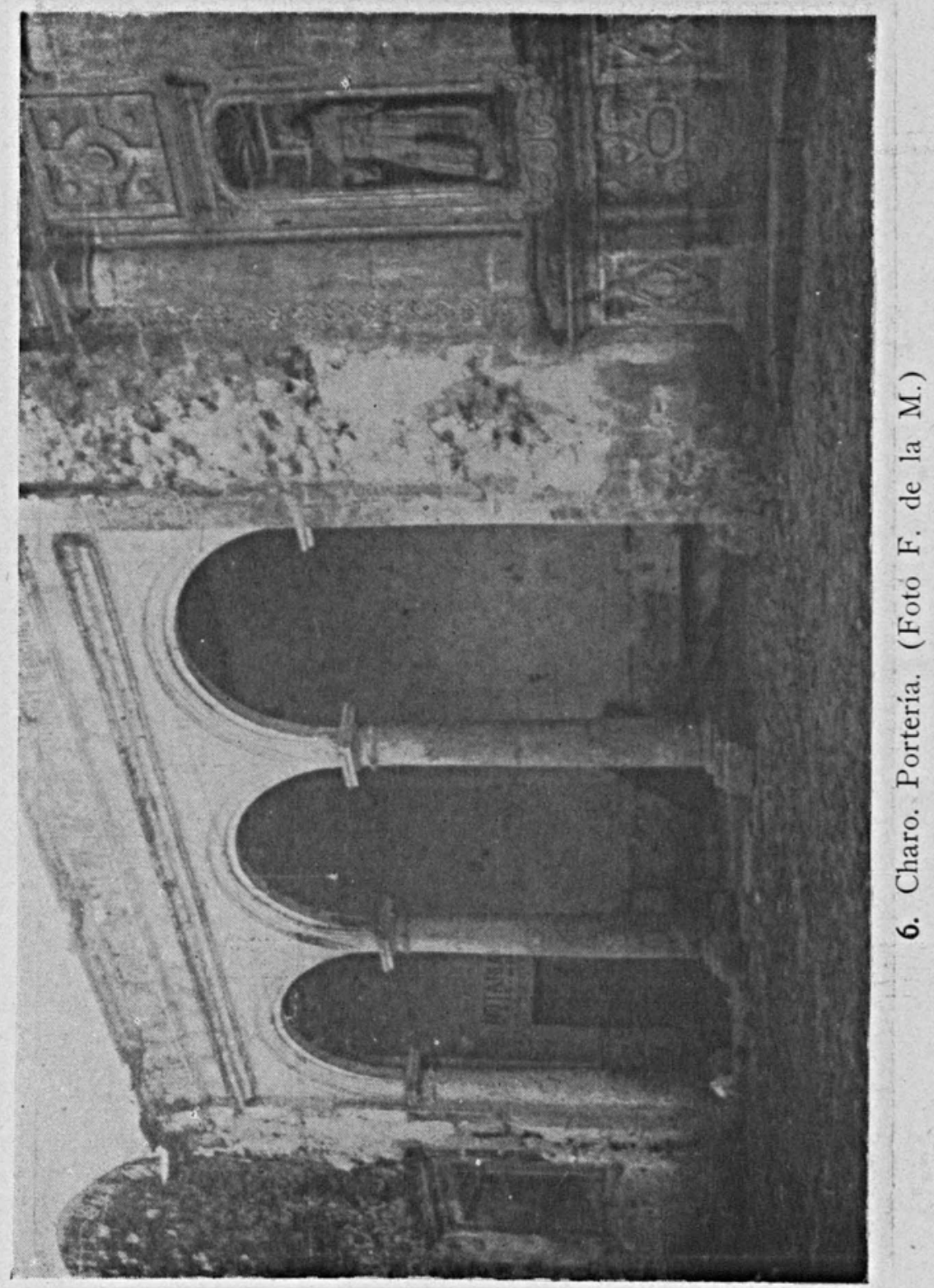


DOI: http://dx.doi.org/10.22201/iie.18703062e.1954.22.575

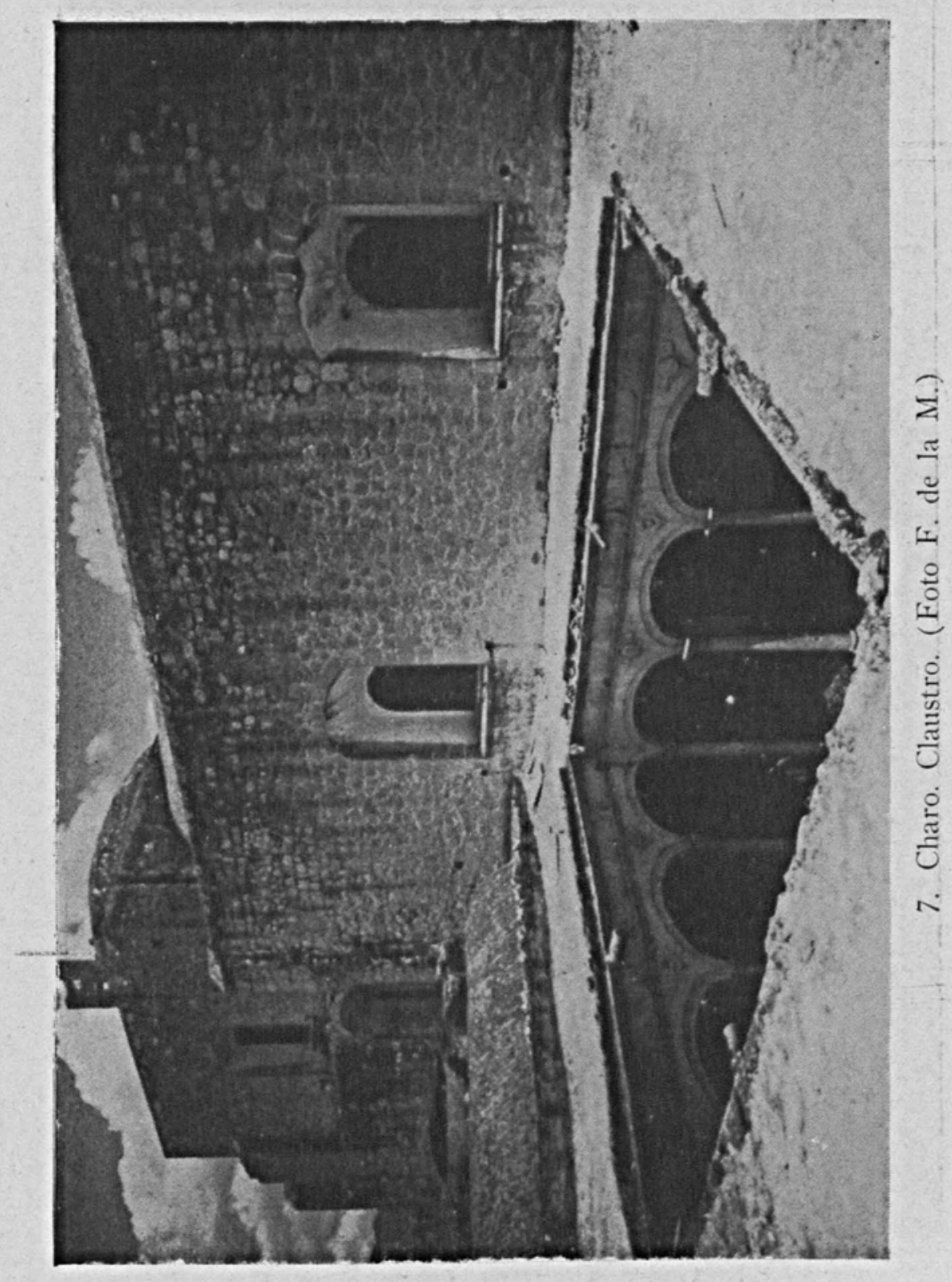




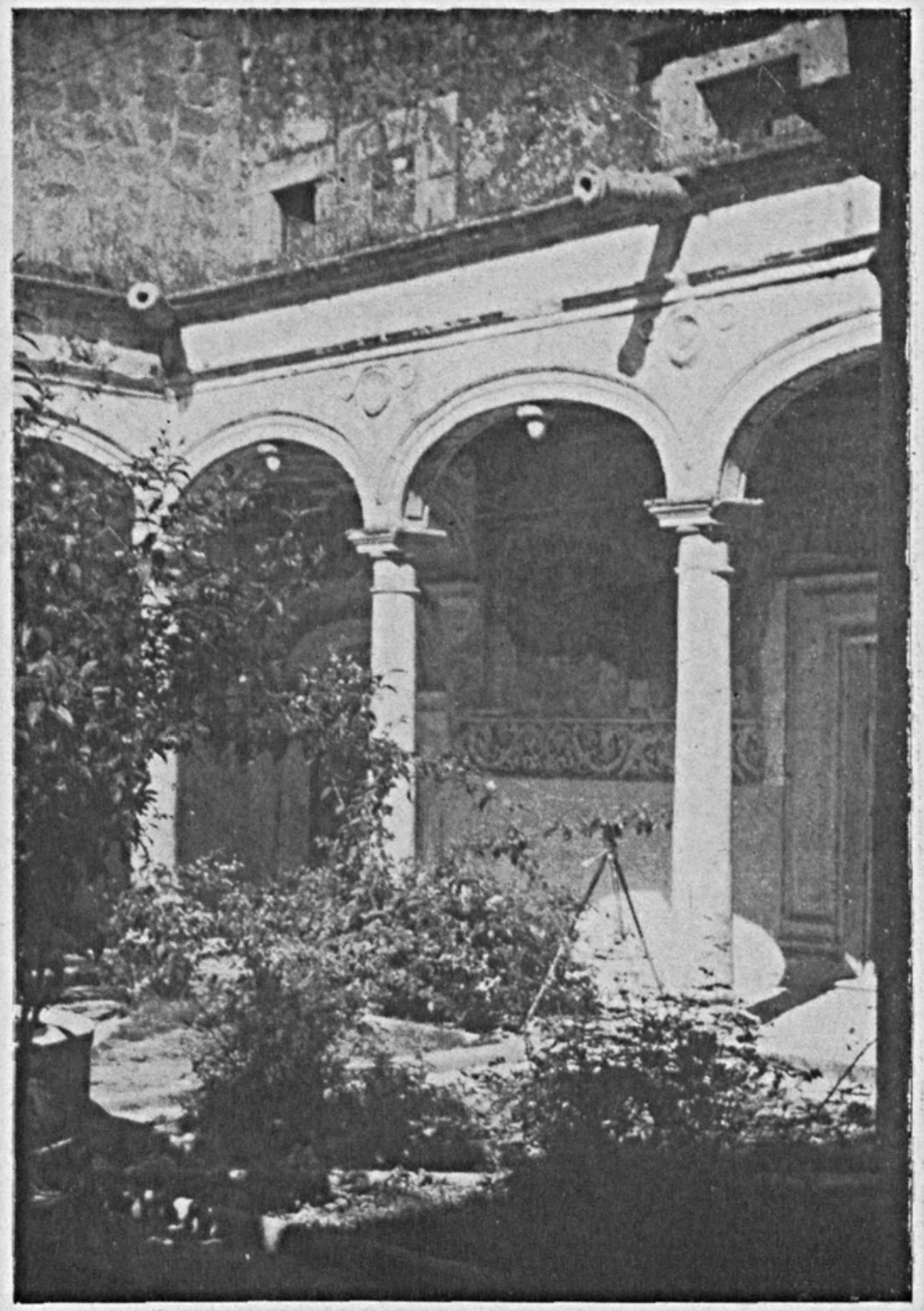

8. Charo. Claustro. (Foto R. F. G.) 
DOI: http://dx.doi.org/10.22201/iie.18703062e.1954.22.575

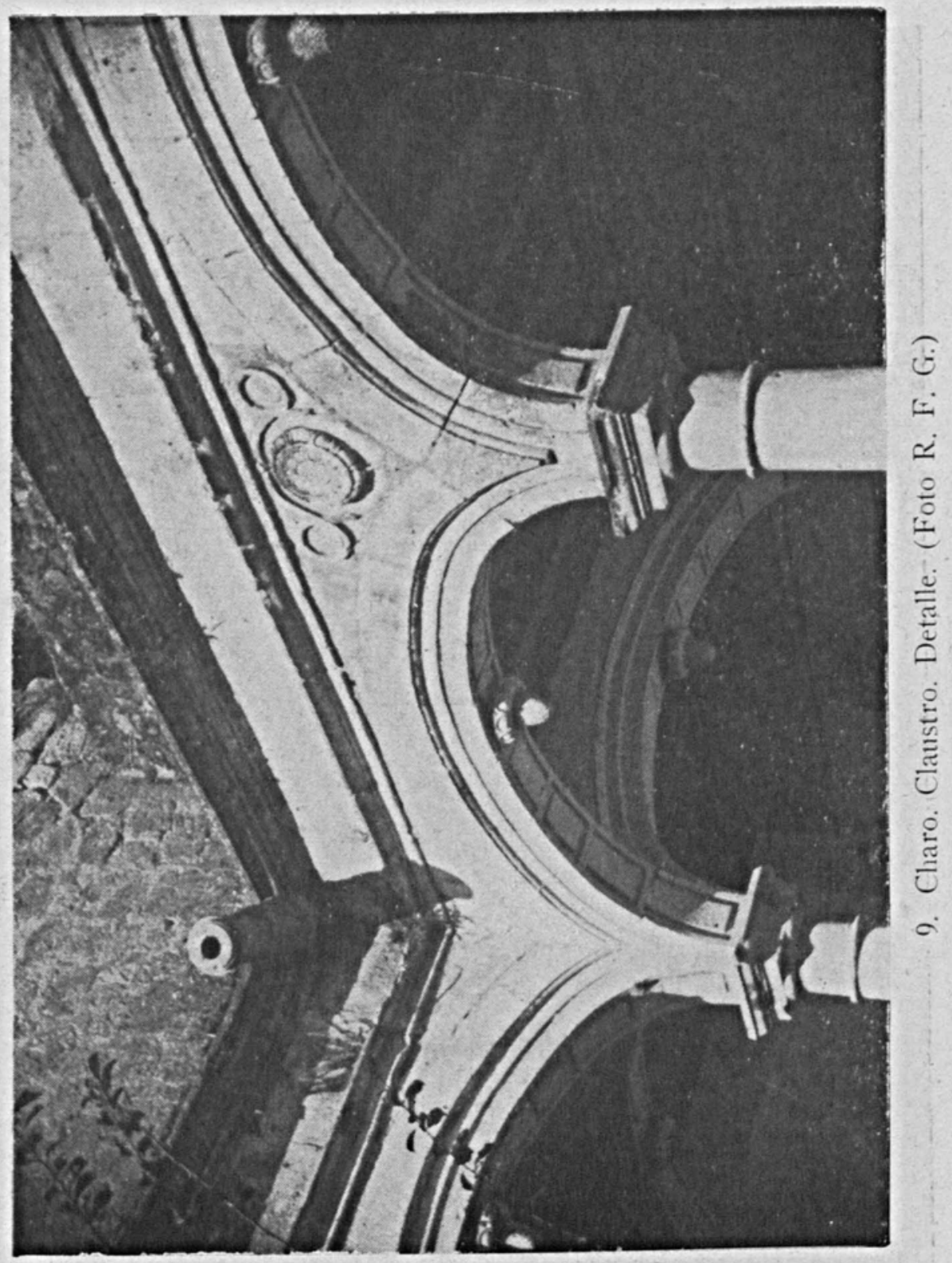


DOI: http://dx.doi.org/10.22201/iie.18703062e.1954.22.575

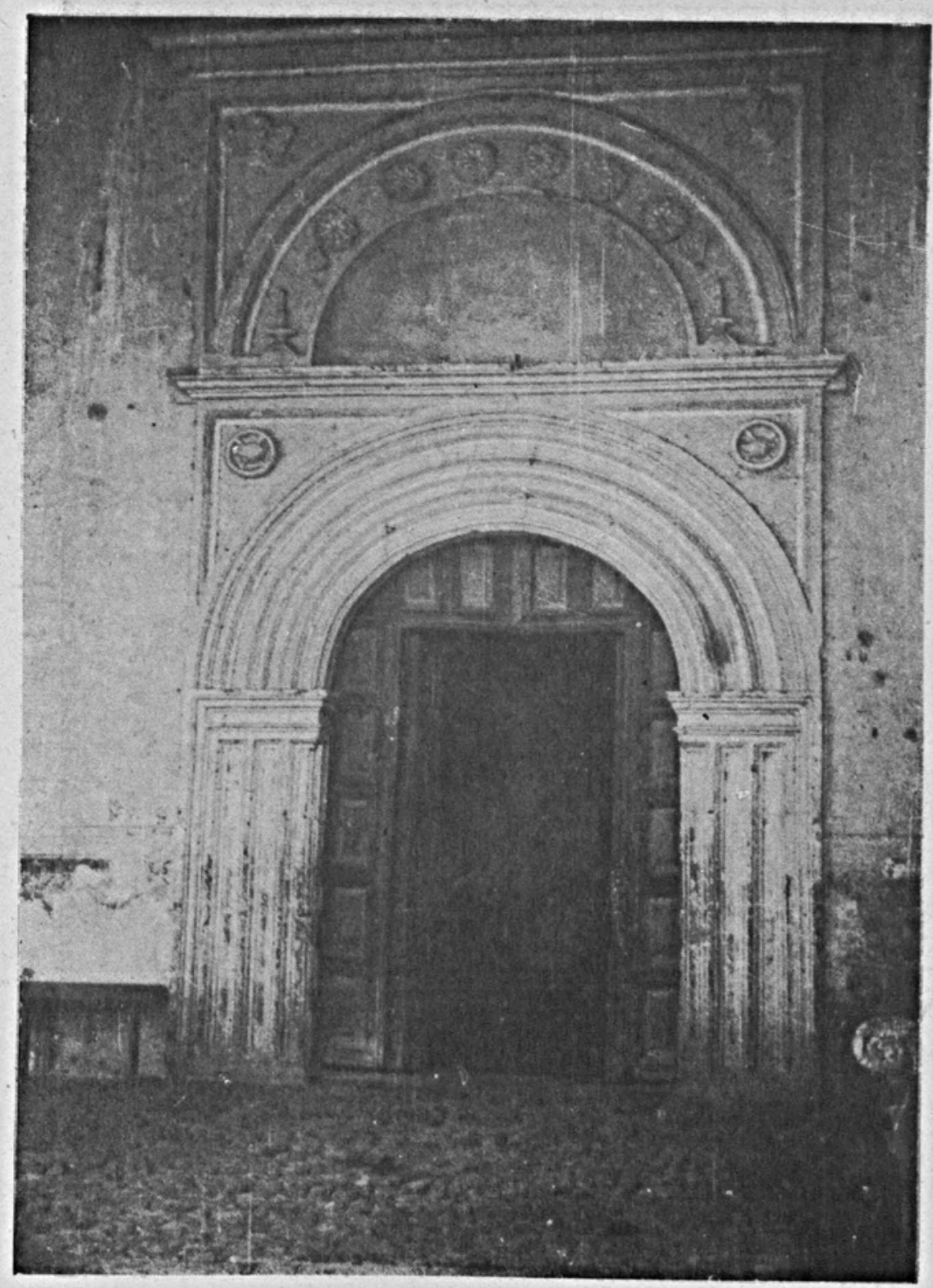

10. Charo. Puerta de la Sacristía. (Foto R. F. G.) 


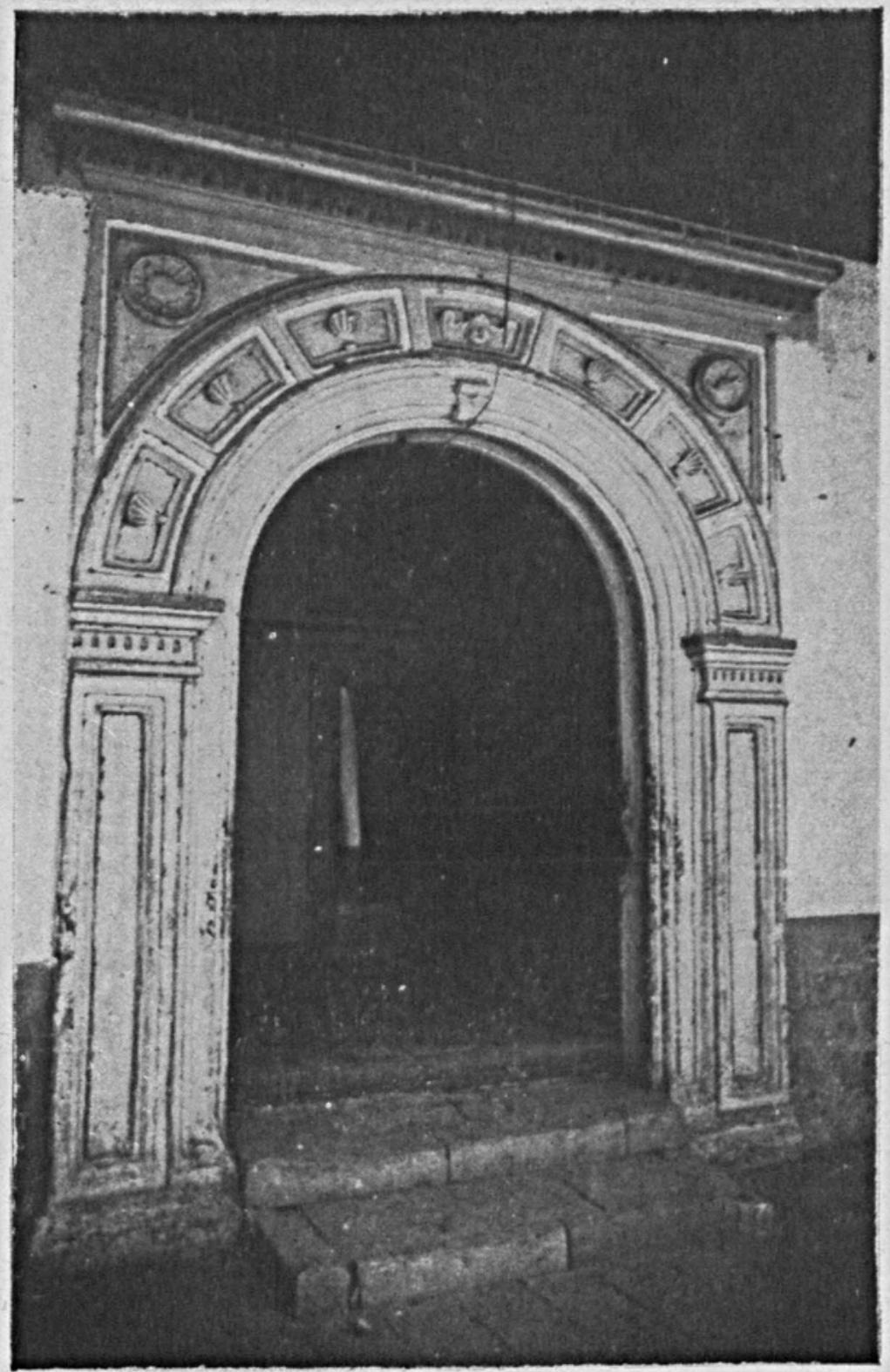

11. Charo. Puerta del Refectorio. (Foto R. F. G.) 

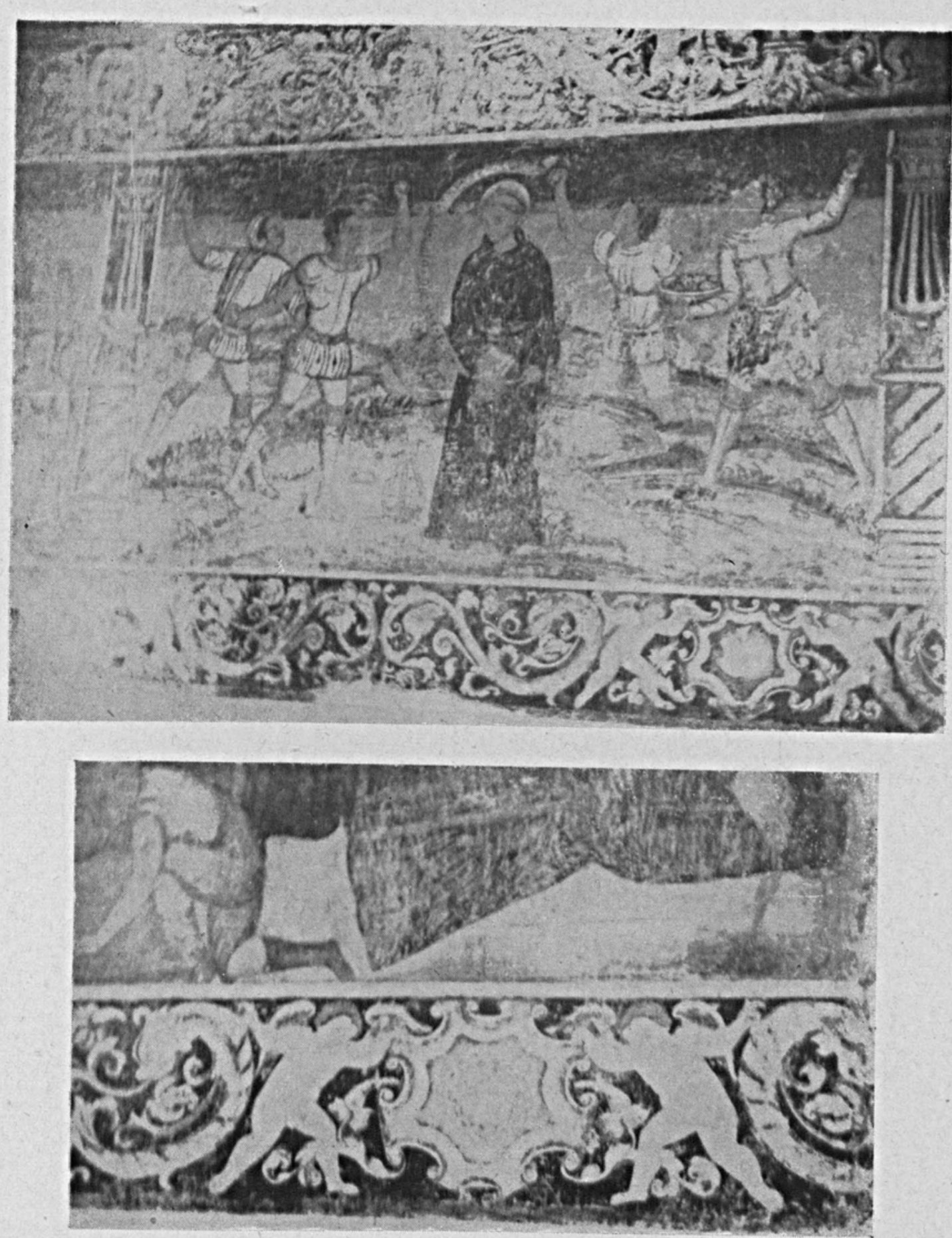

12. Charo. Martirio de un Obispo y detalle de grutesco. (Foto R. F. G.) 


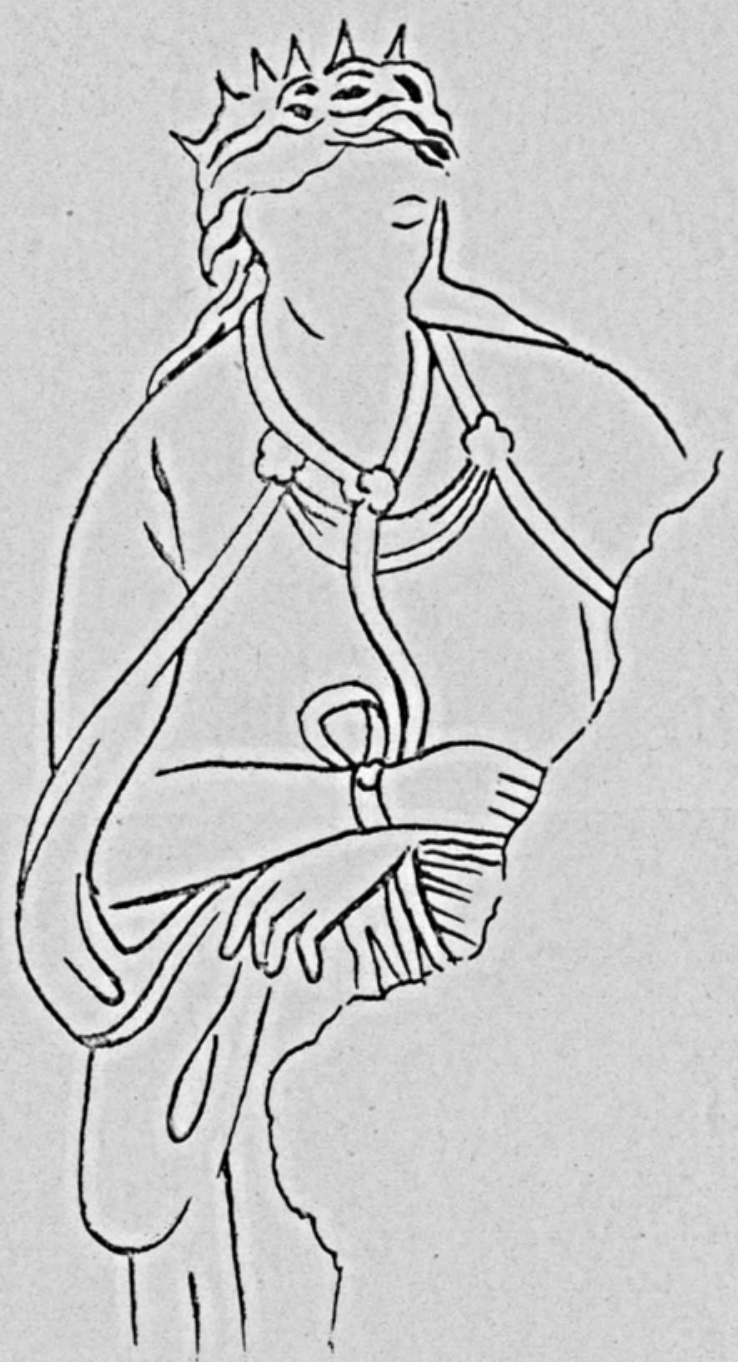

13. Charo. Ecce Homo. (Calca de O. Frías.) 

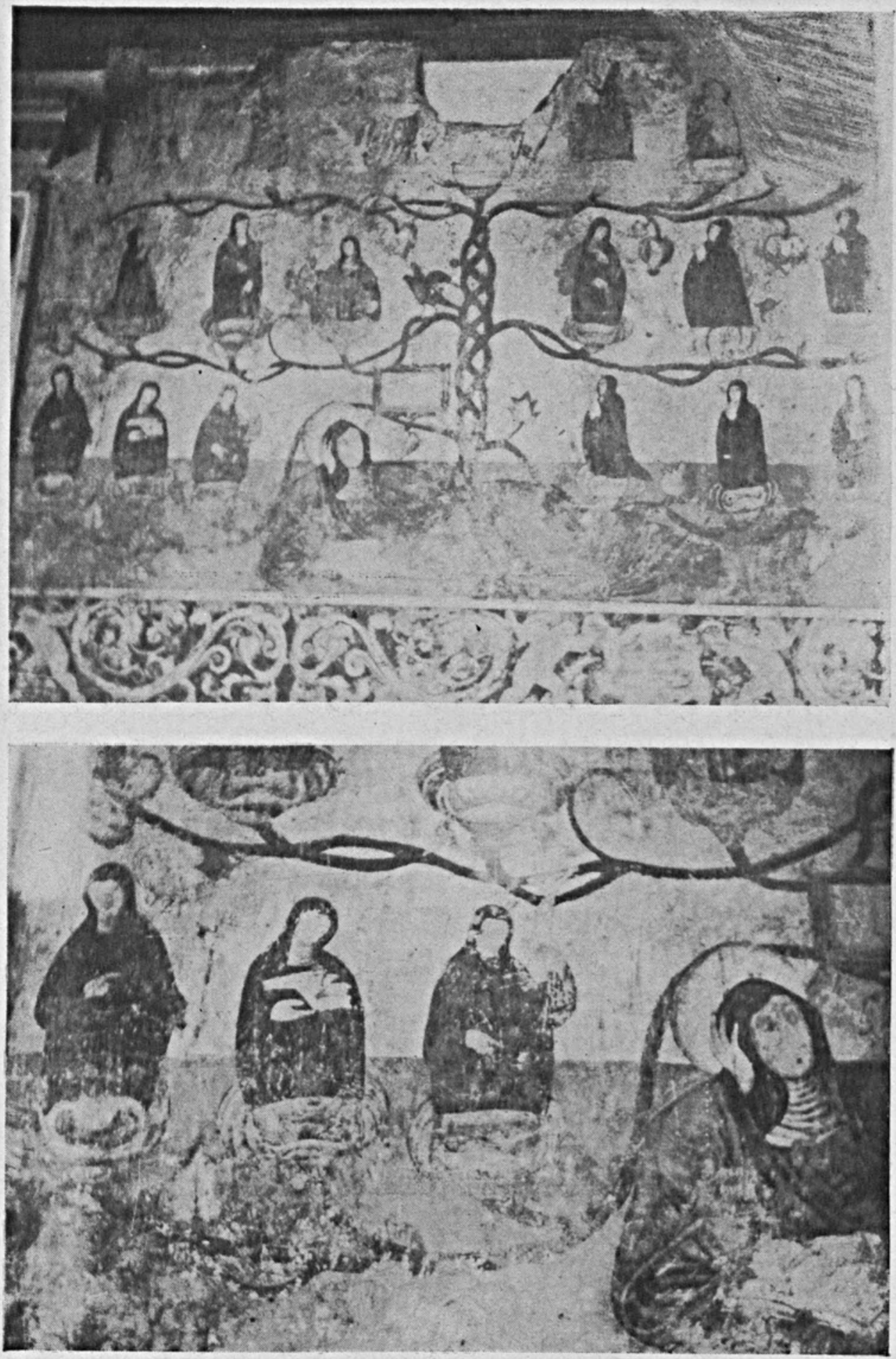

14. Charo. Arbol Genealógico Femenino. (Foto R. F. G.) 

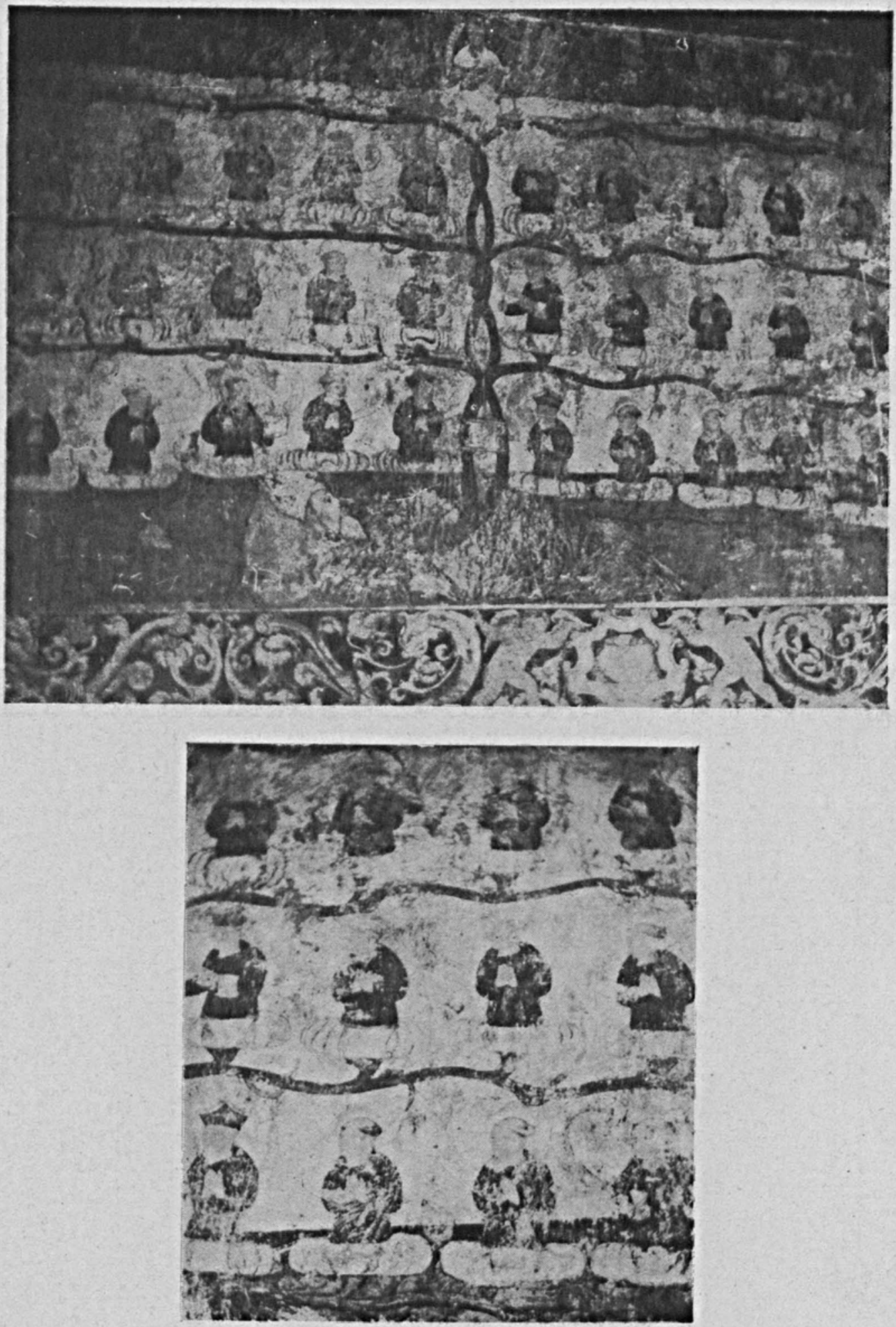

15. Charo. Arbcl Genealógico Masculino. (Foto R. F. G.) 

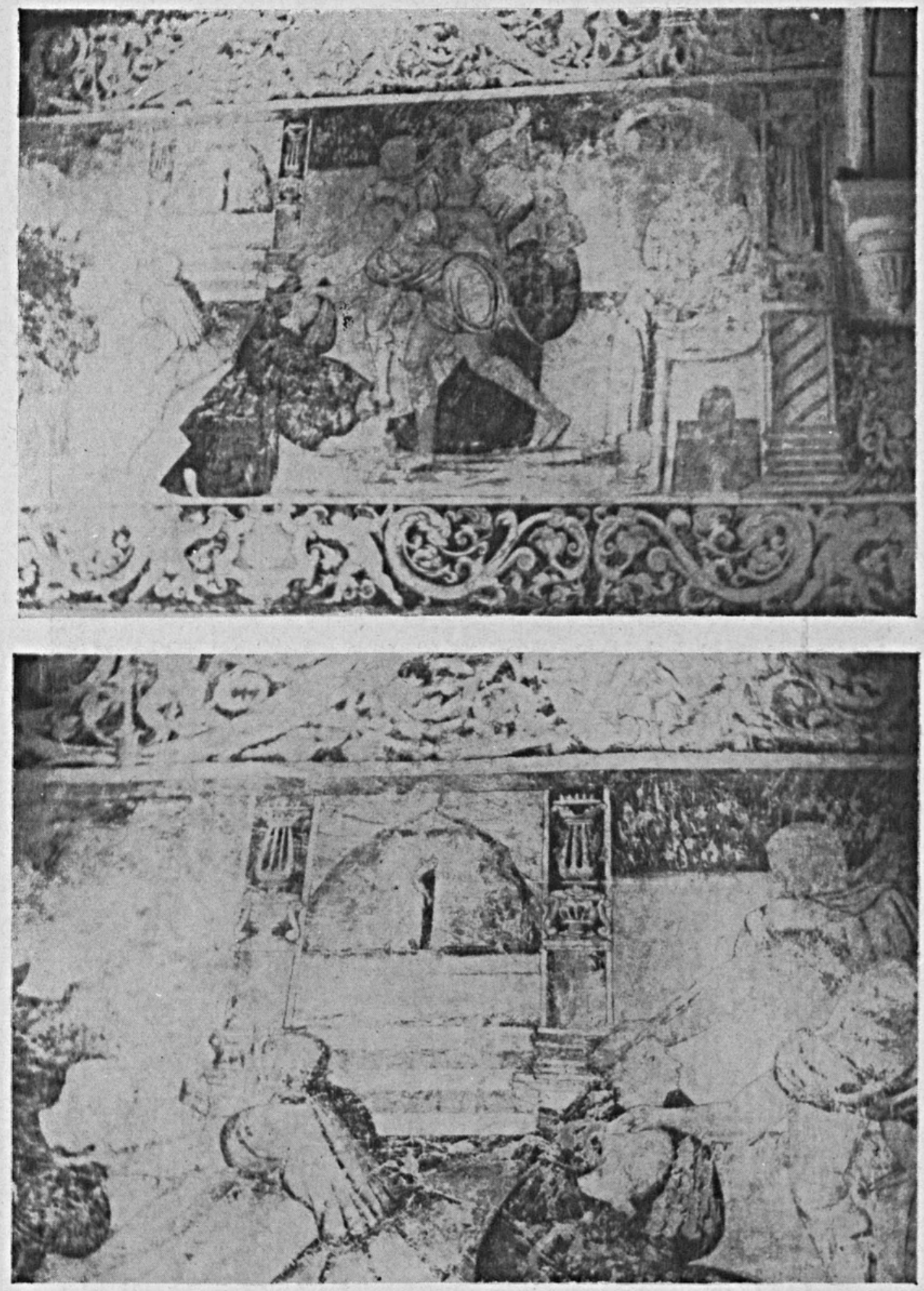

16. Martirio de frailes agustinos. (Foto R. F. G.) 


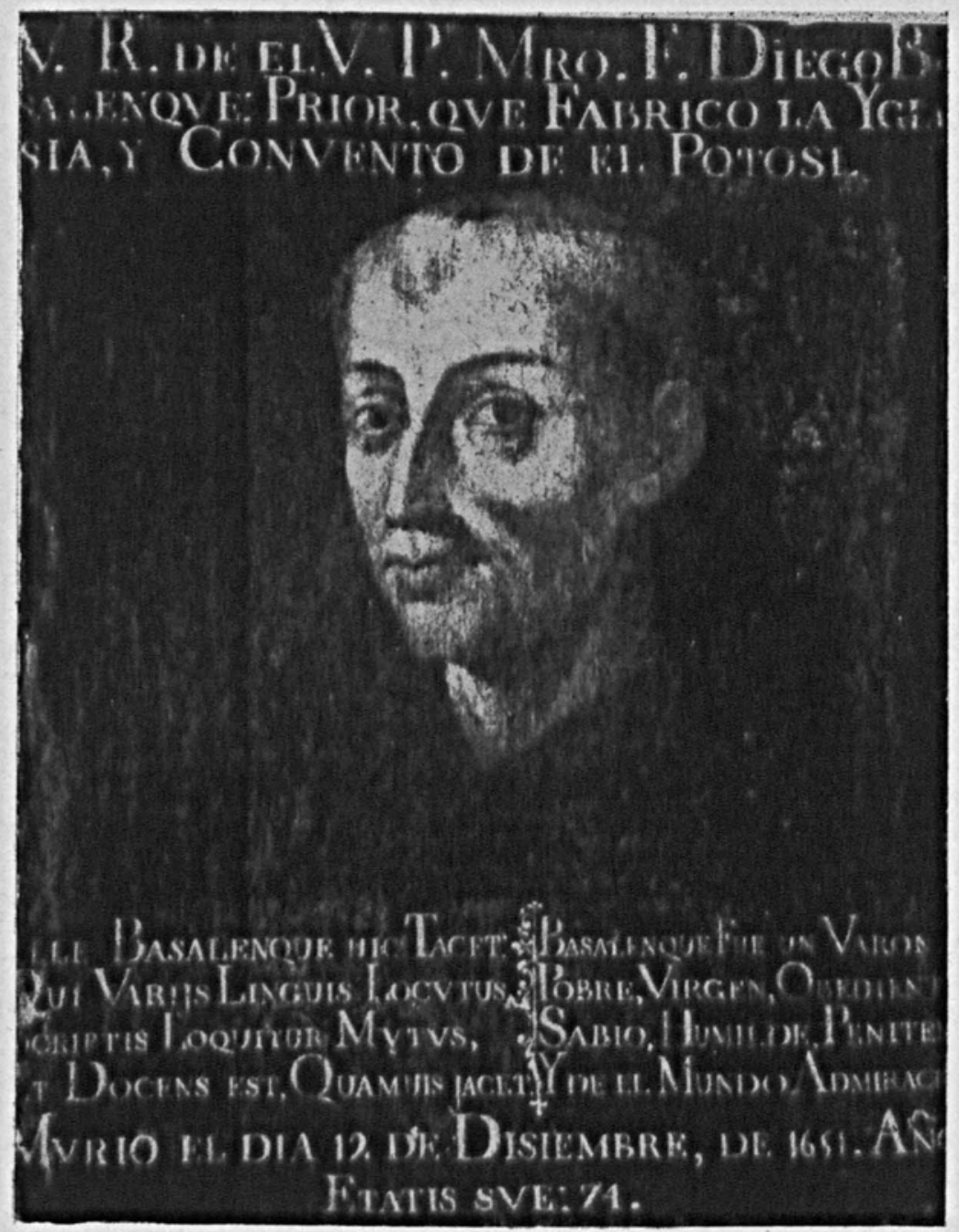

17. Retrato original del Padre Basalenque. (Foto F. de la M.) 
DOI: http://dx.doi.org/10.22201/iie.18703062e.1954.22.575 
Por la Americana Thebaida sabemos también que no sólo el claustro estaba decorado con pinturas al fresco, sino el refectorio, en donde fray Pedro de San Jerónimo "discurrió modo para a un mismo tiempo leer y comer"; no oír leer, como era la costumbre, sino tener ante los ojos, directamente, redondillas piadosas de las que el propio cronista recuerda alguna:

\author{
Santidad y Cruz es una \\ $\mathrm{y} \sin$ cruz, eterno llanto, \\ no hay cruz que no tenga santo \\ ni santo sin cruz alguna
}

acompañadas, éstas, por las figuras de los agustinos más ilustres. ${ }^{13}$

El ambiente de las escenas, el carácter de los lineamientos generales de la composición y los personajes mismos obligan a pensar que éstos, como tantos otros murales del siglo XvI, se inspiraron en grabados de origen europeo, quizás de libros. En este sentido es interesante recurrir a la crónica de Basalenque en donde se refiere que, habiendo prohibido el padre Acosta - segundo prior de Charo- en un exceso de rigidez en la regla conventual, salir de sus celdas a los religiosos "vió a un compañero que estaba mirando los santos de la orden de que está pintado todo el claustro y le preguntó que hacía allí y respondió que mirando a los santos de la orden y él le dijo que mejor fuera que en su celda leyera sus vidas y las imitara". ${ }^{14}$ Es muy posible que de estos mismos libros, cuya lectura recomendaba el padre Acosta a sus frailes, hayan salido los estupendos murales del convento de Charo.

13 Op. cit., pp. 816 y 823.

14 Fr. Diego Basalenque. Historia de la Provincia de San Nicolás Tolentino de Michoacán. México, p. 96. 